\title{
Laparoscopic management of interstitial pregnancy and fertility outcomes after ipsilateral salpingectomy - three case reports
}

\section{Cristina Manea ${ }^{1}$, Evangelia Pavlidou ${ }^{2+}$, Aline Andrey Urias ${ }^{2 \dagger}$, Jean Bouquet de la Jolinière ${ }^{1}$, Jean Bernard Dubuisson ${ }^{1}$ and Anis Feki ${ }^{1}{ }^{*}$}

1 Department of Obstetrics and Gynecology, Hôpital Cantonal Fribourgeois, Fribourg, Switzerland

2 Department of Obstetrics and Gynecology, Geneva University Hospitals, Geneva, Switzerland

\section{Edited by:}

Christine Joséphine Françoise Louise Wyns, Cliniques Univsersitaires Saint Luc, Belgium

Reviewed by:

Frank W. R. C. Vandekerckhove, University Hospital Ghent, Belgium

Mathieu Luyckx, Cliniques

Univsersitaires Saint Luc, Belgium

\section{*Correspondence:}

Anis Feki, Department of Obstetrics and Gynecology, Hôpital Cantonal

Fribourgeois, 1700 Fribourg,

Switzerland

e-mail: anis.feki@gmail.com

${ }^{\dagger}$ Evangelia Pavlidou and Aline Andrey Urias have contributed equally to this work.
Background: Interstitial pregnancy after ipsilateral salpingectomy is a rare event with potentially serious consequences. Optimal management strategy remains uncertain and debated. In addition, fertility sparing is determinant of the treatment choice.

Cases: Here, we report three cases of interstitial pregnancy occurring after homolateral salpingectomy. We expose the therapeutic option held in all three situations, which associated laparoscopic procedure followed by intramuscular methotrexate injection with successful outcome for all patients. We also report the fertility outcome for the first patient, discussing the timing and mode of delivery. Cesarean section at term was performed for this patient.

Conclusion: In these three situations, we obtained a successful result using a minimally invasive surgical approach combined with systemic methotrexate injection. Cesarean section at term for subsequent intrauterine pregnancy seems to be the safest delivery strategy, although no clear data exist in literature.

Keywords: interstitial pregnancy, laparoscopic treatment, minimally invasive laparoscopy, ectopic pregnancy, methotrexate, ipsilateral salpingectomy

\section{INTRODUCTION}

One of the main causes of maternal mortality is the extrauterine pregnancy (1). The interstitial, cornual, and angular pregnancies are often grouped together, despite the fact that their behavior, management, and outcome are different, thus causing confusion in clinical practice. In this article, we will focus on the ectopic pregnancy localized in the interstitial portion of the fallopian tube.

Interstitial pregnancy refers to an ectopic pregnancy that is implanted in the interstitial portion of the fallopian tube, which is defined as the tubal segment traversing the muscular wall of the uterus (2-4). This term also includes the cases of the development of trophoblastic tissue in the remaining tubal part following salpingectomy (5).

Interstitial pregnancy accounts for 1-6\% of all ectopic pregnancies (6) and $2-4 \%$ of all tubal gestations (2). Unfortunately, the mortality rate of interstitial pregnancy still remains at $2-2.5 \%$ (2). The main risk factor for interstitial pregnancy is the antecedent of an ipsilateral salpingectomy (7). Other risk factors for ectopic pregnancy include past pelvic inflammatory disease and salpingitis isthmica nodosa, previous pelvic surgery, and uterine anomalies. Furthermore, the frequency of interstitial implantation has increased from 1.9 to $7.3 \%$ by the use of assisted reproductive techniques (8).

Patient's gestational age, hemodynamic condition, and desire for future pregnancies, as well as the medical center's surgical assets will influence the treatment approach. The surgical option is often chosen for the management of the interstitial pregnancy since at the time of the diagnosis the rupture of the gestational sac is a frequent finding. Nevertheless, in case of early diagnosis with intact gestational sac and hemodynamically stable patients, it is possible to follow a conservative treatment with local or systemic administration of methotrexate (9). Other drugs such as potassium chloride or etoposide (10) have also been used successfully.

Taking into account the progress on the equipment and the expertise in the laparoscopic field during the last years, laparoscopy has justifiably become the most preferable method (4), even replacing laparotomy in certain cases of hemodynamic instability.

This paper reports three cases of laparoscopic therapeutic procedure on ruptured interstitial pregnancies, after prior homolateral salpingectomy.

\section{PATIENT HISTORY}

CASE 1

A 21-year-old woman (gravida 1, para 0) arrived at the emergency department with mild suprapubic pain, described as "menstrual cramps" at 7 weeks of amenorrhea. She had stopped the contraceptive pill some months before without planning on having children immediately. Her medical history included smoking (half a packet per day), asthma, tonsillectomy, and a single incision laparoscopic surgery (SILS) with right salpingectomy for the torsion of a right paratubal cyst 6 months earlier. She was in pain but conscious and well oriented. Her vital signs were normal. The abdominal 
palpation was painful in the right iliac fossa but without guarding or rebound tenderness. Other physical examination findings were normal with the exception of minimal "spotting" bleeding. The urinary pregnancy test was positive, the beta human chorionic gonadotrophin $(\beta$-hCG) was $1574 \mathrm{U} / \mathrm{L}$, and the progesterone was $12.8 \mu \mathrm{g} / \mathrm{L}$. The ultrasonographic (US) examination revealed: a normal-volume anteverted uterus with an endometrial thickness of $16 \mathrm{~mm}$ and a hypoechoic intrauterine image of $3 \mathrm{~mm}$ in diameter, compatible with an eventual gestational sac, without any adnexal mass or intra-abdominal fluid. The patient was reexamined $48 \mathrm{~h}$ later. At that time, the clinical examination and ultrasound findings were identical; the $\beta$-HCG levels increased at $2238 \mathrm{U} / \mathrm{L}$ and the patient was discharged from the hospital with a follow-up appointment in 1 week.

However, $72 \mathrm{~h}$ after the first examination, the patient returned to the hospital with acute abdominal pain, which appeared suddenly during the night. The vital signs were: blood pressure $113 / 80 \mathrm{~mm} \mathrm{Hg}$, heart rate 88 beats/min, temperature $37.5^{\circ} \mathrm{C}$, and oxygen saturation $97 \%$. On abdominal palpation, she was tense and distended, with guarding and rebound tenderness in the right iliac fossa. Gynecologic examination revealed discrete vaginal bleeding and a painful bimanual pelvic exam. The patient's hemoglobin level, white blood cell count, and platelet count on admission were $106,8.8$, and $250 \mathrm{~g} / \mathrm{L}$, respectively. The US revealed a uterine interstitial subserosal mass of $17 \mathrm{~mm} \times 14 \mathrm{~mm}$ and a hypoechogenic image of $15 \mathrm{~mm} \times 15 \mathrm{~mm}$ compatible with fluid in the pouch of Douglas. The patient underwent a diagnostic laparoscopy after a detailed informed consent was signed.

Laparoscopic findings established a diagnosis of a ruptured right interstitial pregnancy with a hemoperitoneum of $100 \mathrm{~mL}$ (Figure 1). The product of gestation was removed by Johan grasping forceps, followed by a remnant right tube expression ("milking" procedure). The hemostasis of the implantation area was performed by bipolar coagulation and the uterine cornu was closed by two single " $\mathrm{X}$ " absorbable sutures.

\section{CASE 2}

A 38-year-old woman (gravida 4, para 1) arrived at the emergency department with an acute suprapubic pain, worsening at mobilization, and 5 weeks of amenorrhea. Her medical history included a normal delivery at 34 weeks 10 years ago, a laparoscopy with right salpingotomy for an ectopic pregnancy 4 years earlier, and a SILS with right salpingectomy for another extrauterine pregnancy 3 months earlier. On initial physical examination, her vital signs were: blood pressure $112 / 70 \mathrm{~mm} \mathrm{Hg}$, heart rate 83 beats/min, and temperature $37.3^{\circ} \mathrm{C}$. She was in pain, but conscious and well oriented. The abdominal palpation was normal with no guarding or rebound tenderness, while the bimanual pelvic exam revealed uterine tenderness, without adnexal tenderness or mass. The patient's hemoglobin level, white blood cell count, and platelet count on admission were $124,8.2$, and $206 \mathrm{~g} / \mathrm{L}$, respectively. On admission, the level of $\beta$-HCG was at $6892 \mathrm{U} / \mathrm{L}$ and the progesterone at $21.1 \mu \mathrm{g} / \mathrm{L}$. The US examination revealed a right retrouterine mass, compatible with a ruptured extrauterine pregnancy, and a hemoperitoneum of about $200 \mathrm{~mL}$. The patient underwent a diagnostic laparoscopy after a detailed informed consent was signed.

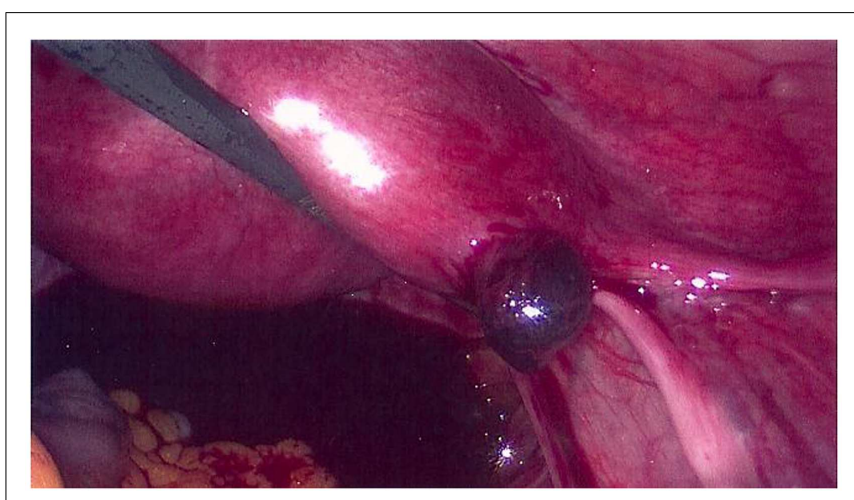

FIGURE 1 | Right interstitial pregnancy after ipsilateral salpingectomy (case 1).

Laparoscopic findings established a diagnosis of a ruptured right interstitial pregnancy with a hemoperitoneum of $600 \mathrm{~mL}$. After removal of the gestation product by Johan grasping forceps, injection of a diluted solution of $0.7 \mathrm{mg}$ of adrenaline circumferentially into the myometrium beneath and lateral to the pregnancy was realized in order to minimize local bleeding. A corneal wedge resection was then performed using a laparoscopic monopolar needle. After washing and checking the incision site, the myometrium was sutured using two single " $\mathrm{X}$ " stitches of 2.0 absorbable threads. The abdominopelvic cavity was then cleaned with Lactated Ringer's solution.

\section{CASE 3}

A 35-year-old woman (gravida 6, para 1) presented at the ER with acute abdominal pain 1 month after in vitro fertilization procedure with a frozen embryo transfer (IVF-ET). Her vital signs were stable apart from decreased blood pressure of 94/52 $\mathrm{mm} \mathrm{Hg}$ without tachycardia. Her past obstetric and gynecologic history included one previous spontaneous birth, one missed pregnancy, and three ectopic pregnancies for which she underwent bilateral salpingectomy. She was at the time treated for secondary sterility for 3 years. On physical examination, the patient's vital signs were stable and she had abdominal guarding and diffuse rebound tenderness. A transvaginal ultrasound scan revealed a left adnexal mass near the left uterine corner and a small intrauterine hypoechogenicity and little free fluid in the pelvis. Blood counts were as follows: hemoglobin: $115 \mathrm{~g} / \mathrm{L}$; WBC: $4.7 \mathrm{~g} / \mathrm{L}$; platelets: $356 \mathrm{~g} / \mathrm{L}$. Her $\beta$-HCG level was $8915 \mathrm{U} / \mathrm{L}$ and the progesterone was $17.3 \mu \mathrm{g} / \mathrm{L}$.

Laparoscopic findings established a diagnosis of a ruptured left interstitial pregnancy (Figure 2). Free peritoneal blood was removed by suction (about $600 \mathrm{~mL}$ ). The tubal wall covered by myometrium was incised with laparoscopic monopolar electrode and the product of gestation removed with grasping forceps and sent to pathology. Hemostasis was maintained by bipolar coagulation. The left uterine horn was closed by three " $\mathrm{X}$ " sutures and reinforced furthermore by stitching the round ligament around the stump (Figure 3). The same procedure was used on the opposite side to allow a median posture of the uterus. A uterine curettage was conducted at the end of operation. The pathology confirmed 


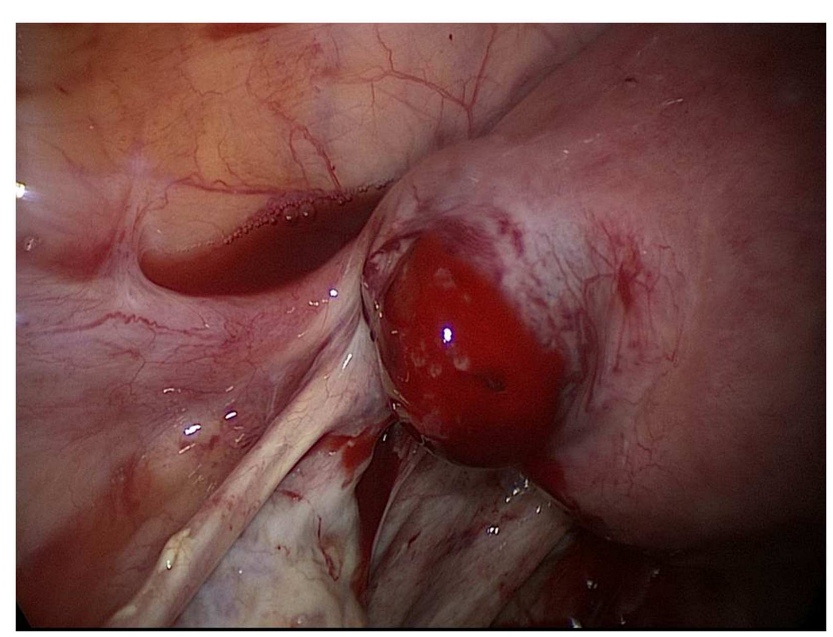

FIGURE 2 | Left interstitial pregnancy after ipsilateral salpingectomy (case 3).

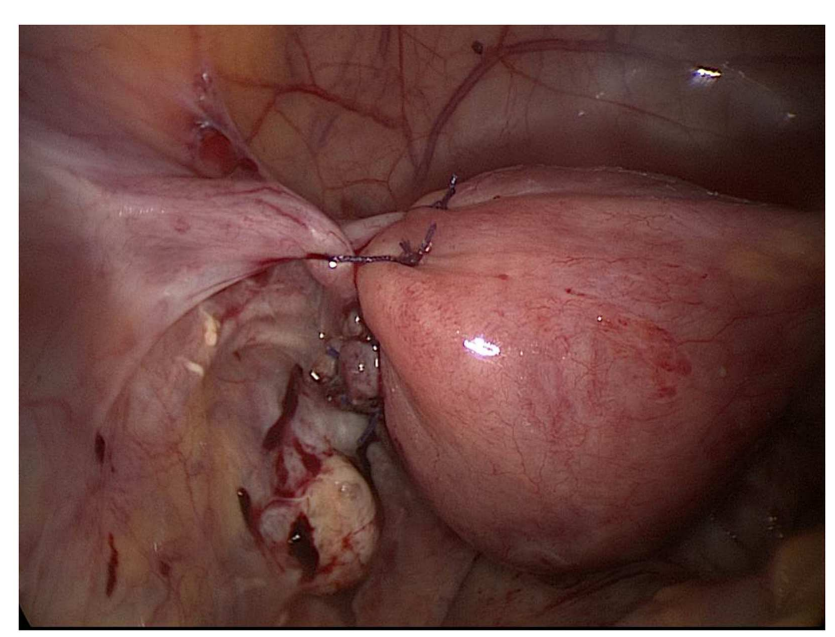

FIGURE 3 | Final result of surgery in case 3.

the presence of trophoblastic cells in the tubal stump and that of the curettage showed images of Arias Stellas.

\section{TREATMENT OUTCOME}

The average operative time was $1 \mathrm{~h}$. The blood loss was minimal for the first patient, while for the second one it was estimated at $900 \mathrm{~mL}$ (hemoperitoneum of $600 \mathrm{~mL}$ and perioperative blood loss of $300 \mathrm{~mL}$ ) a hemoglobin control was performed $6 \mathrm{~h}$ after the operation, revealing an anemia with a hemoglobin level at $93 \mathrm{~g} / \mathrm{L}$. The third case showed similar blood loss of $600 \mathrm{~mL}$ with postoperative hemoglobin of $88 \mathrm{~g} / \mathrm{L}$. Intramuscular methotrexate administration $(1 \mathrm{mg} / \mathrm{kg})$ was performed for all three patients in order to ensure complete regression of the trophoblastic tissue. The postoperative course was uneventful in all cases and they were discharged from the hospital on the first postoperative day. The patients were followed up with $\beta$-HCG measurement on a weekly basis, until the $\beta$-HCG level decreased below $5 \mathrm{U} / \mathrm{L}$ ( 23 and
29 days postoperatively for the first and the second case, respectively). The histological examination confirmed the extrauterine pregnancy. All patients were advised to use an estrogen-progestin contraceptive for at least 6 months after the operation.

Despite medical counseling to avoid pregnancy for at least 6 months, a new pregnancy occurred 2 months after the treatment of the ectopic pregnancy in the first patient. This intrauterine pregnancy was carried out successfully and a cesarean section was performed, resulting in the birth of a healthy child.

\section{DISCUSSION}

The interstitial pregnancy remains one of the rarest types of ectopic pregnancy. With the development of assisted reproduction techniques, an increase in the incidence of such pregnancies could be expected. However, the cases of spontaneous interstitial pregnancy after prior homolateral salpingectomy reported in the literature are still very few.

The risk factors for the interstitial pregnancy are the same as for the other types of ectopic pregnancy (tubal damage from previous ectopic pregnancy, pelvic inflammatory disease, the use of the assisted reproductive technology, prior pelvic operation, tumors, and uterine anomalies), with the exception of ipsilateral salpingectomy, which remains a risk factor unique to interstitial pregnancy $(2,11)$.

As far as the treatment of the interstitial pregnancy is concerned, the conservative methods (i.e., methotrexate) as well as several surgical procedures have been reported. The fact that the blood supply to the region of the intramural tubal segment comes from both uterine and ovarian arteries makes the rupture of an interstitial pregnancy a high-risk incident, often complicated by a severe hemorrhage and higher maternal morbidity and mortality rates than other ectopic pregnancies $(9,12)$. As a result, the conservative method of methotrexate can be attempted only in cases of hemodynamically stable patients with an early stage diagnosis. Certainly, by avoiding the surgical procedure the probability of preserving fertility is increased (12). Local or systemic administration of methotrexate seems to be effective, with an overall success rate of $83 \%$ (2). Some studies suggest that direct corneal methotrexate application might carry higher success rates (13). Other medical treatments showing some success include both etoposide and potassium chloride, both injected directly into the gestational sac under US visualization (14). There has been a report of a heterotopic interstitial and intrauterine pregnancy where the ectopic pregnancy was resolved by injecting (under sonographic guidance) potassium chloride directly into the embryo (15). Similarly, hysteroscopic suction may be attempted, especially if the uterine ostium is dilated (16).

Surgical approach includes the more traditional cornual excision by laparotomy, as well as the newer hysteroscopic, laparoscopic, and minimally invasive techniques, while several combinations of the different therapeutic methods have also been reported. Some years ago, cornual excision by laparotomy was the method of choice for the interstitial pregnancies with a small gestational sac and supravaginal hysterectomy was performed in the more advanced pregnancies (17). However, laparotomy was gradually replaced by laparoscopic techniques because of the advantages in terms of reduced hospitalization, faster recovery, and lower health 
costs (18). Cornual wedge resection, cornuostomy, mini-cornual excision salpingectomy, placing a Vicryl loop on the uterine cornu and salpingotomy are the laparoscopic techniques most frequently reported in the literature, with or without adjuvant methotrexate injection after surgery $(4,19-22)$. It should be noted that the Vicryl loop carries the risk to be placed laterally to the pregnancy (20) and it tends to slip (22), resulting in the failure of the pregnancy's termination and demanding post-surgical supplementary interventions. The technique of aspiration in order to remove out the gestational products is preferable, since their removal gradually with grasping forceps or aspiration may be incomplete (2). In all cases of interstitial rupture, interstitial salpingotomy, and cornual wedge resection, it is necessary to close the uterine horn with absorbable sutures. Alternative surgical methods

Table 1 | Reported interstitial pregnancy management and fertility outcome

\begin{tabular}{|c|c|c|c|c|c|c|}
\hline \multirow[t]{2}{*}{ Reference } & \multirow{2}{*}{$\begin{array}{l}\text { No. of } \\
\text { cases }\end{array}$} & \multicolumn{3}{|c|}{ Management } & \multirow[t]{2}{*}{ Fertility } & \multirow[t]{2}{*}{ Notes } \\
\hline & & MTX i.m & MTX local & Surgical management & & \\
\hline Jermy et al. (2004) (6) & 20 & 17 & - & $\begin{array}{l}2 \text { cornual resection by } \\
\text { laparotomy }\end{array}$ & N.A & $\begin{array}{l}4 \text { cases with fetal heart activity } \\
\text { present ( } 100 \% \text { success) - } 2 \text { cases } \\
\text { with } 2 \text { doses MTX }\end{array}$ \\
\hline $\begin{array}{l}\text { Surbone et al. (2013) } \\
\text { (13) }\end{array}$ & 11 & 3 & $\begin{array}{l}6 * 4 \text { during LSC; } \\
2 \text { transvaginal }\end{array}$ & 2 LSC cornual resection & $\begin{array}{l}9 \\
\text { pregnancies }\end{array}$ & 6 c-section at term \\
\hline $\begin{array}{l}\text { Selma et al. (2009) } \\
\text { (19) }\end{array}$ & 53 & $\begin{array}{l}9 \text { MTX Post- } \\
\text { surgical }\end{array}$ & & $\begin{array}{l}53 \text { LSC; } 33 \text { wedge resection; } 13 \\
\text { cornuostomy; } 7 \text { salpingectomy }\end{array}$ & $\begin{array}{l}18 \\
\text { pregnancies }\end{array}$ & 5 vaginal deliveries, 3 c-sections \\
\hline $\begin{array}{l}\text { Soriano et al. (2008) } \\
(20)\end{array}$ & 27 & 3 & $\begin{array}{l}1 \text { hysteroscopic- } \\
\text { guided injection } \\
\text { in amniotic sac }\end{array}$ & $\begin{array}{l}20 \text { Wedge resection and/or Vycril } \\
\text { loop placement }\end{array}$ & NA & $\begin{array}{l}1 \text { case managed with transvaginal } \\
\text { sonography-guided } \mathrm{KCl} \text { injection to } \\
\text { the amniotic sac }\end{array}$ \\
\hline Siow et al. (2011) (21) & 4 & $\begin{array}{l}2 \text { MTX post- } \\
\text { surgical }\end{array}$ & & $\begin{array}{l}4 \text { LSC wedge resection after } \\
\text { vassopresin injection, repair with } \\
\text { mattress sutures }\end{array}$ & $\begin{array}{l}3 \\
\text { pregnancies }\end{array}$ & $\begin{array}{l}2 \text { c-sections at term and } 1 \text { vaginal } \\
\text { delivery at } 36 \text { gestational weeks }\end{array}$ \\
\hline $\begin{array}{l}\text { Lazard et al. (2011) } \\
\text { (23) }\end{array}$ & 2 & & & $\begin{array}{l}2 \text { SILS cornual resection with } \\
\text { automatic stapler }\end{array}$ & NA & $\begin{array}{l}\text { SILS-single incision laparoscopic } \\
\text { system }\end{array}$ \\
\hline $\begin{array}{l}\text { Young-Sam et al. } \\
\text { (2009) (24) }\end{array}$ & 8 & & & $\begin{array}{l}8 \text { LSC cornuostomy using a } \\
\text { tourniquet suture and } \\
\text { vasopressin inj }\end{array}$ & NA & \\
\hline $\begin{array}{l}\text { Latika et al. (2009) } \\
\text { (25) }\end{array}$ & 2 & & & $\begin{array}{l}2 \text { LSC salpingocentesis with } \\
\text { MTX ( } 50 \mathrm{mg} / \mathrm{kg}) \text { after aspiration } \\
\text { of an equivalent amount of } \\
\text { amniotic fluid }+200 \mathrm{mg} \\
\text { myfepristone p.o. }\end{array}$ & 1 & $1 \mathrm{c}$-section at term \\
\hline $\begin{array}{l}\text { Pluchino et al. (2009) } \\
\text { (33) }\end{array}$ & 1 & & & $\begin{array}{l}\text { LSC cornuostomy and } \\
\text { hemostatic suture }\end{array}$ & NA & \\
\hline $\begin{array}{l}\text { Moon et al. (2000) } \\
(34)\end{array}$ & 24 & $\begin{array}{l}1 \text { MTX post- } \\
\text { operative }\end{array}$ & & $\begin{array}{l}24 \text { LSC; } 15 \text { Endoloop before } \\
\text { evacuation of conceptus; } 3 \\
\text { Encircling suture; vasopressin } \\
\text { injection and electric coagulation }\end{array}$ & $\begin{array}{l}3 \text { missed } \\
\text { abortion; } 1 \\
\text { ectopic } \\
\text { pregnancy; } \\
11 \text { term } \\
\text { pregnancies }\end{array}$ & 11 c-sections at term \\
\hline Tinelli et al. (2010) (14) & 3 & $\begin{array}{l}3 \text { MTX post- } \\
\text { operative }\end{array}$ & & $\begin{array}{l}\text { 3LSC cornuostomy, hemostasis } \\
\text { with bipolar forceps and suture } \\
\text { with } 4 \text { single, } U \text {, sutures of } 0 \\
\text { absorbable monofilament }\end{array}$ & NA & \\
\hline $\begin{array}{l}\text { Simpson et al. (1961) } \\
\text { (7) }\end{array}$ & 6 & & & $\begin{array}{l}3 \text { laparotomies cornual resection; } \\
3 \text { total abdominal hysterectomies }\end{array}$ & $\begin{array}{l}4 \\
\text { pregnancies }\end{array}$ & 4 deliveries at term \\
\hline
\end{tabular}


include the use of laparoendoscopic single-site surgery (23), the use of a temporary tourniquet suture in order to reduce bleeding (24), the laparoscopic salpingocentesis with methotrexate in combination with oral mifepristone (25), and the laparoscopic and ultrasound-guided transcervical evacuation (26). In order to avoid tubal rupture, the possibility of leaving the placenta in situ during transcervical evacuation of the gestational products under abdominal US guidance has also been reported, under the condition that an IM dose of methotrexate should be administered immediately after the operation (27). There are few cases treated by hysteroscopic management under sonographic guidance, or combination of laparoscopy, hysteroscopy, and ultrasound $(28,29)$. Finally, hysterectomy is strictly limited to the cases of uncontrollable hemorrhage, very large interstitial pregnancies, co-existing uterine pathology indicating a hysterectomy or women without fertility desire (4).

Regarding fertility, no differences in terms of pregnancy rates were established between the alternative treatment strategies in tubal ectopic pregnancies, although only limited information is available in literature regarding the specific cases of interstitial pregnancies $(30,31)$ (Table 1). Due to the risk of uterine rupture after an interstitial pregnancy, any subsequent pregnancy should be monitored carefully, and an elective cesarean delivery at term should be preconized to avoid the risk of uterine rupture during labor (32).

Interestingly, there is a lack of data regarding the optimal interval to conception following surgical treatment of an ectopic pregnancy. In our practice, we advise patients to wait approximately 6 months before trying to conceive in order to minimize the risk of uterine rupture.

\section{CLOSING REMARKS}

By the three cases reported here, we confirm that laparoscopy is feasible and can be effective methods for the management of interstitial pregnancies, even when ruptured, in hemodynamically stable patients $(33,35,36)$. We believe that for small ectopic pregnancies, in stable patients with low HCG levels a single dose of systemic MTX can be an effective option.

As there are no sufficient data available regarding the ideal method of treating interstitial pregnancies, the individualized approach in line with the clinician's expertise as well as the patient's clinical features and fertility desire should finally determine the choice of therapeutic procedure acceptable for both parties.

\section{SUPPLEMENTARY MATERIAL}

The Supplementary Material for this article can be found online at http://www.frontiersin.org/Journal/10.3389/fsurg.2014.00034/ abstract

\section{REFERENCES}

1. Khan KS, Wojdyla D, Say L, Gülmezoglu AM, Van Look PF. WHO analysis of causes of maternal death: a systematic review. Lancet (2006) 367(9516):1066-74. doi:10.1016/S0140-6736(06)68397-9

2. Lau S, Tulandi T. Conservative medical and surgical management of interstitial ectopic pregnancy. Fertil Steril (1999) 72(2):207-15. doi:10.1016/S00150282(99)00242-3

3. Jansen RP, Elliott PM. Angular intrauterine pregnancy. Obstet Gynecol (1981) 58(2):167-75.
4. Moawad NS, Mahajan ST, Moniz MH, Taylor SE, Hurd WW. Current diagnosis and treatment of interstitial pregnancy. Am J Obstet Gynecol (2010) 202(1):15-29. doi:10.1016/j.ajog.2009.07.054

5. Jourdain O, Fontanges M, Schiano A, Rauch F, Gonnet JM. Management of other ectopic pregnancies (cornual, interstitial, angular, ovarian). J Gynecol Obstet Biol Reprod (Paris) (2003) 32:S93-100.

6. Jermy K, Thomas J, Doo A, Bourne T. The conservative management of interstitial pregnancy. BJOG (2004) 11:1283-8. doi:10.1111/j.1471-0528.2004. 00442.x

7. Simpson JW, Alford CD, Miller AC. Interstitial pregnancy following homolateral salpingectomy. A report of 6 new cases and review of the literature. Am J Obstet Gynecol (1961) 82:1173-9.

8. Pisarska MD, Carson SA. Incidence and risk factors for ectopic pregnancy. Clin Obstet Gynecol (1999) 42(1):2-8. doi:10.1097/00003081-199903000-00004

9. Zalel Y, Caspi B, Insler V. Expectant management of interstitial pregnancy. Ultrasound Obstet Gynecol (1994) 4(3):238-40. doi:10.1046/j.1469-0705.1994. 04030238.x

10. Chen CL, Wang PH, Chiu LM, Yang ML, Hung JH. Successful conservative treatment for advanced interstitial pregnancy. A case report. J Reprod Med (2002) 47(5):424-6.

11. Tulandi T, Al-Jaroudi D. Interstitial pregnancy: results generated from the Society of Reproductive Surgeons Registry. Obstet Gynecol (2004) 103(1):47-50. doi:10.1097/01.AOG.0000109218.24211.79

12. Malinowski A, Bates SK. Semantics and pitfalls in the diagnosis of cornual/interstitial pregnancy. Fertil Steril (2006) 86(6):.e11-4. doi:10.1016/j. fertnstert.2006.03.073

13. Surbone A, Cottier O, Vial Y, Francini K, Hohlfeld P, Achtari C. Diagnosis and management of interstitial pregnancy - a series of eleven cases. Swiss Med Wkly (2013) 143:w13736. doi:10.4414/smw.2013.13736

14. Tinelli A, Malvasi A, Pellegrino M, Pontrelli G, Martulli B, Tsin DA. Laparoscopical management of cornual pregnancies: a report of three cases. Eur J Obstet Gynecol Reprod Biol (2010) 151(2):199-202. doi:10.1016/j.ejogrb.2010.03.032

15. Savelli L, Fabbri F, Di Donato N, De Meis L. Heterotopic interstitial pregnancy successfully treated with ultrasound-guided potassium chloride injection in the ectopic embryo. J Obstet Gynecol (2014) 34(3):276-7. doi:10.3109/01443615. 2013.861394

16. Minelli L, Landi S, Trivella G, Fiaccavento A, Barbieri F. Cornual pregnancy successfully treated by suction curettage and operative hysteroscopy. BJOG (2003) 110:1132-4. doi:10.1111/j.1471-0528.2003.03088.x

17. Ballantyne EN, Murray K, Fraser RJ. Interstitial pregnancy after homolateral salpingectomy: (report of a case). Can Med Assoc J (1940) 43(6):560-2.

18. Baumann R, Magos AL, Turnbull A. Prospective comparison of videopelviscopy with laparotomy for ectopic pregnancy. Br J Obstet Gynaecol (1991) 98(8):765-71.

19. Ng S, Hamontri S, Chua I, Chern B, Siow A. Laparoscopic management of 53 cases of cornual ectopic pregnancy. Fertil Steril (2009) 92(2):448-52. doi:10.1016/j.fertnstert.2008.08.072

20. Soriano D, Vicus D, Mashiach R, Schiff E, Seidman D, Goldenberg M. Laparoscopic treatment of cornual pregnancy: a series of 20 consecutive cases. Fertil Steril (2008) 90(3):839-43. doi:10.1016/j.fertnstert.2007.07.1288

21. Siow A, Ng S. Laparoscopic management of 4 cases of recurrent cornual ectopic pregnancy and review of literature. J Minim Invasive Gynecol (2011) 18(3):296-302. doi:10.1016/j.jmig.2011.02.002

22. Tulandi T, Vilos G, Gomel V. Laparoscopic treatment of interstitial pregnancy. Obstet Gynecol (1995) 85(3):465-7. doi:10.1016/0029-7844(94)00423-B

23. Lazard A, Poizac S, Courbiere B, Cravello L, Gamerre M, Agostini A. Cornual resection for interstitial pregnancy by laparoendoscopic single-site surgery. Fertil Steril (2011) 95(7):e5-8. doi:10.1016/j.fertnstert.2011.03.056

24. Choi YS, Eun DS, Choi J, Shin KS, Choi JH, Park HD. Laparoscopic cornuotomy using a temporary tourniquet suture and diluted vasopressin injection in interstitial pregnancy. Fertil Steril (2009) 91(5):1933-7. doi:10.1016/j.fertnstert. 2008.02.013

25. Narang L, Kalu G. Laparoscopic salpingocentesis using methotrexate in combination with oral mifepristone for successful treatment of interstitial pregnancy: a case report. Fertil Steril (2009) 92(6):.e5-7. doi:10.1016/j.fertnstert. 2009.08.016

26. Thakur Y, Coker A, Morris J, Oliver R. Laparoscopic and ultrasound-guided transcervical evacuation of cornual ectopic pregnancy: an alternative approach. J Obstet Gynaecol (2004) 24(7):809-10. doi:10.1080/01443610400009576 
27. Ross R, Lindheim SR, Olive DL, Pritts EA. Cornual gestation: a systematic literature review and two case reports of a novel treatment regimen. J Minim Invasive Gynecol (2006) 13(1):74-8. doi:10.1016/j.jmig.2005.11.005

28. Sanz LE, Verosko J. Hysteroscopic management of cornual ectopic pregnancy. Obstet Gynecol (2002) 99:941-4. doi:10.1016/S0029-7844(02)01664-2

29. Pal B, Akinfenwa O, Harrington K. Hysteroscopic management of cornual ectopic pregnancy. BJOG (2003) 110(9):879-80. doi:10.1111/j.1471-0528.2003. 02198.x

30. Turan V. Fertility outcomes subsequent to treatment of tubal ectopic pregnancy in younger Turkish women. J Pediatr Adolesc Gynecol (2011) 24(5):251-5. doi:10.1016/j.jpag.2010.12.007

31. MacRae R. Diagnosis and laparoscopic management of 11 consecutive cases of cornual ectopic pregnancy. Arch Gynecol Obstet (2009) 280(1):59-64. doi:10. 1007/s00404-008-0872-4

32. Agdi M, Tulandi T. Surgical treatment of ectopic pregnancy. Best Pract Res Clin Obstet Gynaecol (2009) 23(4):519-27. doi:10.1016/j.bpobgyn.2008.12. 009

33. Pluchino N, Ninni F, Angioni S, Carmignani A, Genazzani AR, Cela V. Spontaneous cornual pregnancy after homolateral salpingectomy for an earlier tubal pregnancy: a case report and literature review. J Minim Invasive Gynecol (2009) 16(2):208-11. doi:10.1016/j.jmig.2008.11.008

34. Moon HS, Choi YJ, Park YH, Kim SG. New simple endoscopic operations for interstitial pregnancies. Am J Obstet Gynecol (2000) 182(1):114-21. doi:10.1016/ S0002-9378(00)70499-6
35. Grimbizis GF, Tsalikis T, Mikos T, Zepiridis L, Athanasiadis A, Tarlatzis BC, et al. Case report: laparoscopic treatment of a ruptured interstitial pregnancy. Reprod Biomed Online (2004) 9(4):447-51. doi:10.1016/S1472-6483(10)61282-5

36. Chan LY, Yuen PM. Successful treatment of ruptured interstitial pregnancy with laparoscopic surgery. A report of 2 cases. J Reprod Med (2003) 48(7):569-71.

Conflict of Interest Statement: The authors declare that the research was conducted in the absence of any commercial or financial relationships that could be construed as a potential conflict of interest.

Received: 17 June 2014; accepted: 18 August 2014; published online: 05 September 2014. Citation: Manea C, Pavlidou E, Urias AA, Bouquet de la Jolinière J, Dubuisson JB and Feki A (2014) Laparoscopic management of interstitial pregnancy and fertility outcomes after ipsilateral salpingectomy - three case reports. Front. Surg. 1:34. doi: 10.3389/fsurg.2014.00034

This article was submitted to Gynecology and Obstetrics, a section of the journal Frontiers in Surgery.

Copyright (c) 2014 Manea, Pavlidou, Urias, Bouquet de la Jolinière, Dubuisson and Feki. This is an open-access article distributed under the terms of the Creative Commons Attribution License (CC BY). The use, distribution or reproduction in other forums is permitted, provided the original author(s) or licensor are credited and that the original publication in this journal is cited, in accordance with accepted academic practice. No use, distribution or reproduction is permitted which does not comply with these terms. 